\title{
Political Crisis and Societal Governance: How Media Can be Societal Media?
}

\author{
Toru Takahashi
}

Faculty of Law, Chuo University, Japan

\begin{abstract}
Political frustration of the people often comes along with protest movements on the streets. The street democracy becomes most powerful when the political system loses the people's systemic trust. Therefore, we can see the street democracy as a symptom of the systemic political crisis. We have to be vigilant for political adventurism that exploits the people's discontent. However, considering the chronic fiscal deficits of governments, we cannot rely only on governments. We have to expand our view beyond politics and governments. We are facing various problems at local, national and global levels. It is necessary to develop societal governance that mobilizes and organizes multi-functional resources to cope with the multi-level challenges. As J.N. Rosenau formulates, governance is an encompassing phenomenon that embraces governmental and non-governmental mechanisms. This paper reformulates the comprehensiveness of societal governance as multi-functionality and multi-levelness. It means that societal governance is an ecosystem of collaborative efforts that mobilizes multi-functional resources to cope with public problems across local, national and global levels. Innovations in media (especially, in the Internet) can contribute to creating fertile conditions for the efforts by advocating issues and connecting actors and resources. Media can make another step to a next stage of the development as liaison media in societal governance. Now we are witnessing the next step of the media's development towards "societal media".
\end{abstract}

url:

\section{Introduction.}

Political disappointment and frustration of the people often come along with protest movements on the streets. Max Weber writes, "It (the democracy of the street) is at most powerful in countries with a parliament that is either powerless or politically discredited" (Weber, 1994, p.231). "Street" democracy becomes most powerful when the political system fails to represent the people's political interests and loses their systemic trust. Therefore, we can see street democracy as a symptom of the systemic political crisis.

Sociology and its neighboring disciplines have discussed the conditions of underperformance of governments. Daniel Bell writes that there are many "fault lines" which could fragment nation-states (for instance, linguistic and national lines in Belgium; linguistic in Canada; religious in Northern Ireland; local nationalistic in Spain; tribal in Nigeria). However, he does not think such "fault lines" themselves could be major risks for nation-states. Rather, he thinks there is a common underlying structural problem. He writes, "the nation-state is becoming too small for the big problems of life, and too big for the small problems of life" (Bell, 1988). While nation-states have been facing the toobig-too-small problem, a variety of civil networks and international organizations have grown their capability to cope with many kinds of small (local) and big (global) problems. We can see the trend

Corresponding author: Toru Takahashi; e-mail: t-taka@tamacc.chuo-u.ac.jp 
of societal change from another point of view. Scholars of public administration and international relations (IR) and political scientists have been discussing the trend under the phrase "from government to governance". Jon Pierre and B. Guy Peters refer to eight explanations of the rising interest in governance studies (Pierre and Peters, 200o, pp.52-67). (1) The growing budget deficits and debts of governments and the decline in state capacities during 1980s and 1990s. (2) The ideological shift from politics towards market (as we saw in the policies of Margaret Thatcher and Ronald Reagan). (3) Globalization has changed the precondition of domestic policy-making because governments have become more dependent on the expertise that is provided by international institutions such as the European Union. Moreover, increasing borderless mobility of corporations has undermined the states' leverage over international corporations. This situation has stimulated forming new countermeasures against the mobility of corporate sector. (4) States' failure to live up to expectations from a broad range of constituencies has become increasingly obvious. Popular frustration has grown, and "in many countries parties advocating more or less extreme but unspecified 'change' such as the 'Progress' parties in Denmark and Norway, the D66 in the Netherland, the Austrian Freedom Party or why not Ross Perot in the United States became popular" (Pierre and Peters, 200o, p.62). (5) The growing interest in the New Public Management tells us that states' leverage over public service production and delivery has also decreased. (6) The "postmaterial" issues ${ }^{1}$ concerning quality-of-life have come to the fore as important social-political issues. This change has increased the complexity of policy-making and made governments more dependent on expertise to handle these issues. (7) New sources of regional and international governance such as the European Union, World Trade Organization, and International Monetary Fund have increased their importance. (8) The emergence of the new sources of governance has stimulated debates over accountability.

From a sociological point of view, it is interesting that the diversity of social problems is one of the major backgrounds of the rise of governance studies. Jan Kooiman raises a question: how can dynamic, complex and diverse society be governed in a democratic and effective way. His answer is that "governing and governance itself should be dynamic, complex and varied" (Kooiman, 1993, p.36). However, our society is still struggling and developing to be more dynamic, complex and diverse locally as well as globally. Moreover, it is uncertain whether the process will be successful or not. We will stay in an unstable, transitional phase until the society builds sophisticated governability. Therefore, the Bell's too-big-too-small problem of nation-states will linger, especially as underperformance and chronic fiscal deficits of governments, in the foreseeable future.

\section{Political conflicts as exploiting parasites on society}

The underperformance of governments provides opposition parties and newly risen political parties with a political chance to criticize ruling parties. If things go well, they can get political momentum to increase their seats in parliaments. Of course, this is a usual political scene in representative democracy. However, there is also a risk that political parties only provoke the people's emotion without proposing realistic and feasible policies to gain popularity. Such situation can easily lead to antagonism between "true representatives" of the people and enemies of the people's interests. Moreover, if the mass media circulate the antagonism, dualistic and uncompromising political conflicts will be constructed. In a case of Japanese politics, a schema "righteous reformer versus oldguard cronies" was dramatized with moralistic tone on the screen of television during the 2005 general election. ${ }^{2}$ Such a dramatized politics is brought about by the combination of performances of politics and the mass media (Takahashi, in press). It is quite doubtful whether such a mediamediated, emotion-led political conflict could contribute to coping with difficulties that society faces. Niklas Luhmann describes conflicts as (not symbiotic but exploiting) parasites on society. As Georg Simmel and Lewis A. Coser discussed, conflicts could have a social function such as unifying 
effect (Simmel, 2009; Coser, 1956). However, conflicts have immanent drive to develop themselves by stepping up the antagonism. "The parasitism is typically not designed for symbiosis but tends to draw the host system into conflict to the extent that all attention and all resources are claimed for the conflict" (Luhmann, 1995, p.390). Once a conflict becomes fierce, it tends to exploit all resources (especially the people's emotion) as much as possible and jeopardize social stability. ${ }^{3}$ It is likely that this kind of political process will not lead to solutions of social problems, but rather become another social problem.

We have to be vigilant for political adventurism that exploits the people's political frustration caused by social problems (such as social inequality) and resorts to emotion-based politics to get political momentum. In his typology of political leadership, Michitoshi Takabatake categorizes this kind of political style as "speculative leadership". He warns that such a leadership can hardly find feasible solutions and, what is worse, it adopts ad hoc policies that often contradict each other and look for their "enemy" inside and/or outside the society (Takabatake, [1976]2012, pp.236-237). To avoid this kind of political style, we have to develop policy-based politics further. However, considering chronic and huge fiscal budget deficits among governments, such improvement of the political system is not enough. As Luhmann writes, we cannot see politics as a central steerer of whole society that is ethically responsible for everything (Luhmann, 1981, p.23). Therefore, we have to expand our view beyond politics.

\section{From politics to societal governance}

We are facing various problems at local, national and global levels. However, given the financial deficits of governments, politics is not the only thing that matters, but also and rather the society itself does matter. R.A.W. Rhodes writes, "(c)entral government is no longer supreme. The political system is increasingly differentiated. We live in 'the centreless society' " (Rhodes, 1997, p.51). His remark does not mean the end of government. Rather it reflects a change in the relationship between state and civil society and suggests that we need a comprehensive notion that describes the whole picture. Rhodes even thinks that "governance blurs the distinction between state and civil society" (Rhodes, 1997, p.57). J.N. Rosenau formulates that governance is an encompassing phenomenon that embraces governmental and non-governmental mechanisms to cope with difficulties that we face (Rosenau, 1992, p.4). Rosenau's definition of "encompassing" governance is based upon the distinction between governmental and non-governmental. Kooiman also introduces a concept of encompassing governance. "Governing can be seen as the totality of interactions, in which public as well as private actors participate, aimed at solving societal problems or creating societal opportunities" (Kooiman, 2003, p.2). He calls such governance with totality as "socialpolitical governance". The hyphenated adjective "social-political" refers to a mix of two kinds of actors: the public and the private. He writes, "governance of and in modern society is a mix of all kinds of governing efforts by all manner of social-political actors, public and private" (Kooiman, 2003, p.1). He also uses the term "societal governance" in his work. By these terms, he describes the multidimensional nature of governance in modern society.

These understandings of comprehensiveness of governance are all based on binary distinctions: state/civil society, governmental/non-governmental, public/private. However, from a sociological point of view, these binary distinctions are too simple to describe the diversity of societal life. These binary distinctions describe as if there were only two spheres in the societal world. We know that, on the side of "civil society", "non-governmental" and "private" of these distinctions, there are economic transactions, scientific studies, artistic activities, learning, journalism and so forth. Governance can utilize and organize products and activities of each functional domain in modern society. For instance, policy- and law-makings in politics, judicial rulings in the court, economic transactions, 
scientific findings and technologies, artistic expressions and works, broadly shared information through the mass media, the nurturing of human resources in education and so forth can contribute to tackling public problems. In this respect, the comprehensiveness of governance can be reformulated as multi-functionality. In the contemporary globalized society, governance has not only multi-functionality but also multi-levelness because our problems extend across distinct societal levels, namely local, national and global levels. ${ }^{4}$

In modern society, each functional domain enjoys its autonomy. Luhmann describes the autonomy on the basis of the theory of autopoietic systems (Luhmann, 1997). From the viewpoint of actors in societal governance, autonomous functional systems constitute their societal environment. ${ }^{5}$ Actors can obtain their resources from the societal environment, or rather depends on the products and activities of functional systems. How societal governance gets contributions from functional systems is a key challenge to build a successful problem solving.

Societal governance is not a kind of social system as function systems are in Luhmann's social systems theory. It is rather, to use the term "system", an ecosystem ${ }^{6}$ of various actors who make efforts on public problems cooperatively and sometimes competitively across local, national and global levels. As discussed above, autonomous functional systems constitute the societal environment for these actors. Societal governance has no powerful center that controls or even coordinates itself. ${ }^{7}$ In consequence, actors in societal governance sometimes face difficulties to build collaborative relations and to obtain their resources from their societal environment. Therefore, societal governance needs a new type of media that mediates between actors, and between actors and resources. ${ }^{8}$ Besides, efforts in societal governance cannot have as much legitimacy as governmental efforts. The legitimacy of societal efforts depends on public acknowledgement that the targeted problems are "public" and the efforts are supposed to contribute to making things better. ${ }^{9}$ A problem becomes public when it is advocated in the name of collective interest (Enderlein, Wälti, \& Zürn, eds. 2010, p.2).${ }^{10}$ Media also play an important role to set public agenda from local to global level, and this contribution of media would encourage efforts in societal governance. As our task is to realize the full potential of the "centreless", functionally differentiated society, developing the new type of media is a key issue that we have to consider from the viewpoint of sociocybernetics. We will discuss a new conception of media in the next section.

\section{What is societal media?}

It is networks of collaborative communications that realize societal governance. Innovations in communication media (especially in the Internet) can contribute to creating fertile conditions for societal governance by disseminating information and connecting needs, actors, and resources. Talking about the word "media", it generally means "the mass media" that enable mass communications from specialized agents such as newspapers and broadcast stations to their readers and audiences. Luhmann discussed the function of the mass media as a differentiated social system in modern society. He sees the function of the mass media as generating societal memory. In society, such "memory consists in being able to take certain assumptions about reality as given and known about in every communication" (Luhmann, 2000, p.65). Broadly shared information disseminated by the mass media takes an important role as "given" and "known" grounds of our communications. The mass media created a huge number of passive recipients of one-way mass communications ("the masses"). Since we stepped into the Internet age, a new type of media has appeared: "social media". In contrast to the mass media, social media's home ground is personal communication. They create a huge number of personal connections and networks and enrich our professional and private lives. However, in terms of building societal governance, this recent development is still not enough. Media can make another step to a next stage of the development, and now we are witnessing the 
next step of the development towards "societal media". This paper categorizes media that help societal efforts as societal media. "Societal efforts" mean efforts that constitute societal governance. Societal media help societal efforts in following aspects. (1) They help societal efforts to set agenda and goals by communicating and advocating public problems. (2) They also help actors to obtain their resources such as funds and staff. (3) They help actors to build their networks and facilitate their collaboration. We can also call such media as societal liaison media because societal media mediate between actors, and between actors and their societal environment.

Recently, we can find good examples of societal media in these three aspects. (1) A civic report site is an example of the first aspect. It is a platform of civic contributions that report problems of roads, parks, and other public space at local level. On FixMyStreet and SeeClickFix ${ }^{1}{ }^{1}$, leading cases of civic report platforms, people can report many kinds of problems in their communities such as broken street lights, graffiti, fly-tipping, potholes and so forth. Then the platforms send the reports to fixers such as local governments as liaison actors between reporters and fixers. ${ }^{1} 2$ Through the activity, these civic report platforms set common goals to be achieved. Of course, the traditional mass media can make such contributions at each societal level by covering public problems. For instance, SeeClickFix has media partners such as the Washington Post and the Toronto Star that cover and advocate issues reported on the platform.

(2) Societal media mediate between actors and resources. Crowdfunding sites are good examples of this second aspect. Razoo ${ }^{13}$ is one of well-known crowdfunding sites. It helps fundraisers to find their donors for their causes, and donors can find campaigns that they want to help on the platform. Societal media also mediate actors who want to participate in societal efforts and actors who are looking for their partners to enhance their efforts. For instance, volunteer matching sites connect volunteers and organizations. Taproot $+{ }^{14}$, one of volunteer matching sites, helps skilled volunteers to find non-profit organizations that fit their skills and non-profit organizations to find their skilled volunteers.

(3) Societal media connect actors who are making their efforts in the ecosystem of societal governance. The examples referred in the first and second aspects are also contributors in this aspect because willing citizens, generous donors, and skilled volunteers are actors in societal governance when they get involved. On a campaign platform site such as Causes ${ }^{15}$, actors can support each other according to their causes. The development of Causes has been tightly connected to social media such as Facebook to increase its membership. In this respect, social media have prepared a fertile condition for the development of societal media. Looking at organizational actors, another kind of example comes in sight. Infrastructure organizations (bodies) such as The National Council for Voluntary Organisations in the United Kingdom, National Council of Nonprofits and Independent Sector in the United States connect and support NPOs more systematically than societal media ${ }^{16}$. For instance, National Council of Nonprofits provides NPOs with helpful guidance about ethics, accountability, financial management, human resources management and fundraising. It also issues free e-newsletters to share "policy issues affecting the nonprofit sector" and "trends and insights on nonprofit operations" ${ }^{17}$. California Association of Nonprofits, the infrastructure organization in the state of California, enhances the advocacy of member organizations to the state legislature, state government, and the public. Such organizations are sometimes called "intermediary" organizations. Intermediary organizations in the non-profit sector are "engaging, convening and supporting critical stakeholders; promoting quality standards and accountability; brokering and leveraging resources; and advocating for effective policies" (Anheier \& List, 2005, p.136) ${ }^{18}$. Though these are not pure cases of societal media, it is worthwhile to note the importance of the intermediary function for societal governance. The roles of societal media are limited, compared to the roles of the full-fledged support organizations. However, as discussed above, societal media play an important role in the 
ecosystem of societal governance. Societal media do not have to be managed by large-scale organizations to help societal governance. They can be managed by relatively small groups who have skills in information and communication technology. Such agility of societal media provides societal governance with new possibilities of its development.

\section{Conclusion}

As we have seen above, various media take important roles as liaison media in societal governance. As societal governance has no central organizer and coordinator, it needs the liaison media that play intermediary roles. In a sense, societal governance is nothing more or less than the efforts of building the social order. From Talcott Parsons to Niklas Luhmann, "how social order is possible" has been a fundamental question of sociology. In this respect, to study the question "how societal governance is possible" is almost equivalent to tackling the fundamental sociological question. However, there is a small but important difference between the two questions. The former does not include private or personal problems because societal governance copes with only public problems that are advocated in the name of the collective interest, while the latter includes private affairs such as intimacy. The distinction between the public and the private draws this fault line. On the private side of the distinction, people create and develop their relationship through social media. On the public side, societal media can contribute to societal governance through setting goals, brokering resources and facilitating collaborations. If we want to maintain and develop the level of social diversity and complexity that modern society has attained, developing the centreless societal governance is a necessary task. The wave of societal media will provide flexible and helpful contributions for us. Emerging societal media have begun to show a new horizon of the development of societal governance.

\section{Acknowledgement}

I would like to express my gratitude to my colleagues and reviewers for insightful comments and helpful suggestions.

\section{References}

Albertazzi, D. \& McDonnell, D. (Eds.). (2008). Twenty-First Century Populism: The Spectre of Western European Democracy. New York: Palgrave Macmillan.

Anheier, H. K., \& List, R. A. (2005). A Dictionary of Civil Society, Philanthropy and the Third Sector, London: Routledge.

Bell, D. (1988, January 3). Previewing Planet Earth in 2013. The Washington Post, p.B3.

Berry, J. M. (1999). The New Liberalism: The Rising Power of Citizen Groups. Washington, D.C.: Brookings Institution Press.

Cabinet Office, Government of Japan. (2002). The Report on the Current Status and Issues of the Intermediary Organizations [in Japanese]. Retrieved Jury 30, 2015, from https://www.npo-homepage.go.jp/toukei/ 2009izen-chousa/2oogizensonota/2ooinposhien-report

Coser, L. A. (1956). The Functions of Social Conflict. London: Routledge \& K. Paul. 
Enderlein., H., Wälti, S., \& Zürn, M. (Eds.). (2010). Handbook on Multi-Level Governance. Cheltenham: Edward Elgar.

Hooghe, L. \& Marks, G. (2003). Unraveling the Central State, but How? Types of Multi-Level Governance. The American Political Science Review, Vol. 97, No. 2, 233-243.

Hooghe, L. \& Marks, G. (2004). Contrasting Visions of Multi-level Governance. In I. Bache \& M. Flinders (Eds.), Multi-level Governance. Oxford: Oxford University Press, pp.15-30.

Hooghe, L. \& Marks, G. (2010). Types of Multi-level governance. In H. Enderlein, S. Wälti, \& M. Zürn (Eds.), Handbook on Multi-Level Governance. Cheltenham: Edward Elgar, pp.17-32.

Kendall, J. (Ed.) (2009). Handbook on Third Sector Policy in Europe: Multi-level Processes and Organized Civil Society. Cheltenham: Edward Elgar.

Kooiman, J. (1993). Governance and Governability: Using Complexity, Dynamics and Diversity. In J. Kooiman (Ed.), Modern Governance: New Government-Society Interactions. London: Sage, 35-48.

Kooiman, J. (1999). Social-political Governance: Overview, Reflections and Design. Public Management, 1(1), 67-92.

Kooiman, J. (2003). Governing as Governance. London: Sage.

Luhmann, N. (1981). Politische Theorie im Wohlfahrtsstaat. München: Olzog.

Luhmann, N. (1995). Social Systems. Stanford: Stanford University Press.

Luhmann, N. (1997). Die Gesellschaft der Gesellschaft. Frankfurt am Mein: Suhrkamp.

Luhmann, N. (200o). The Reality of Mass Media. Stanford: Stanford University Press.

Matuszek, K.C. (2007). Der Krieg als autopoietisches System: Die Kriege der Gegenwart und Niklas Luhmanns Systemtheorie. Wiesbaden: VS Verlag.

Moore, J.F. (1993). Predators and Prey: A New Ecology of Competition. Harvard Business Review, May-June, 75-86.

O'Reilly, T. (2009). Gov 2.0: The Promise of Innovation. Forbes. Retrieved Jury 30, 2015, from http://www.forbes.com/2009/o8/10/ government-internet-software-technologybreakthroughs-oreilly.html

Otake, H. (2006). Koizumi Junichiro: Populism no Kenkyu [Junichiro Koizumi: A Case Study of Populism. Tokyo: Toyo Keizai. [in Japanese]

Pierre, J., \& Peters, B. G. (2000). Governance, Politics and the State. Basingstoke: Palgrave Macmillan.

Rhodes, R.A.W. (1997). Understanding Governance: Policy Networks Governance, Reflexivity and Accountability. Buckingham: Open University Press. 
Rosenau, A.N. (1992). Governance, Order, and Change in World Politics. In: J.N. Rosenau and E-O. Czempiel (Ed.) Governance without Government: Order and Change in World Politics. Cambridge: Cambridge University Press.

Scott, B. (1980). The Cybernetics of Gordon Pask (part 1). International Cybernetics Newsletter, 17, 327-336.

Schneider, W. L. (2007). Religio-politischer Terrorismus als Parasit. In: T. Kron \& M. Reddig (Hrsg.), Analysen des Transnationalen Terrorismus: Soziologische Perspektiven. Wiesbaden: VS Verlag, 125-165.

Simmel, G. (2009). Sociology: Inquiries into the Construction of Social Forms. Leiden: Brill.

Takabatake, M. ([1976]2012). Seijigaku he no Michi-Annai [A Guide to Political Science]. Tokyo: Kodansha. [in Japanese]

Takahashi, T. (in press). Populism and Moralization of Politics in the Age of Systemic Crisis: A Sociocybernetic Case Study of Japanese Politics. The Chuo Law Review, 122(11/12), 124.

von Foerster, H, Brun, H, Easley, J. A. Jr, Lehman, F. K, Weston, P. E \& Witz, K. G. (1972). Cognitive technology: A citizen-society problem solving interface. Research Proposal Submitted to the National Science Foundation, Biological Computer Laboratory, Urbana, Ill.

Weber, M. (1994). Parliament and Government in Germany. In P. Lassman (Ed.), Weber: Political Writings. Cambridge: Cambridge University Press.

\footnotetext{
${ }^{1}$ On the postmaterial issues as congressional agenda in the United States, see Berry (1999). The major advocates of the postmaterial issues are citizen groups. Berry argues that, "the postmaterial issues on the congressional agenda are closely linked to the advocacy of citizen groups" (Berry, 1999, p.65).

${ }^{2}$ In this context, it is worthwhile to refer populism studies. Danielle Albertazzi and Duncan McDonnell define populism as "an ideology which pits a virtuous and homogeneous people against a set of elites and dangerous 'others' who are together depicted as depriving ... the sovereign people of their rights, values, prosperity, identity and voice"(Albertazzi \& McDonnel, 2008, p.3). Clearly, we can see moralistic nature of populism in this definition. Otake (2006) also points out the moralistic nature of populism in his case study on Japanese politics.

${ }^{3}$ Schneider (2007) applies the Luhmann's concept of "parasite" to the relationship between terrorism and society. Matuszek (2007) also applies it to analyze the destructive effect of armed conflicts to society.

${ }^{4}$ We can increase the number of levels by adding, for instance, "regional" and "supra-national" levels.

However, the relevance of distinctions of levels consists in describing borderlessness of collaborative efforts in societal governance rather than in expressing closeness of each level. In this point, the distinction between two - general-purpose and task-specific - types of multi-level governance by Hooghe and Marks (2003, 2004, 2010) is helpful for further elaboration of the concept of multi-levelness of societal governance.

${ }^{5}$ In this point, my conception of societal governance is connected to the legacy of Luhmann's societal theory (Gesellschaftstheorie).

${ }^{6}$ James F. Moore writes, in a business ecosystem "they (companies) work cooperatively and competitively to support new products, satisfy customer needs, and eventually incorporate the next round of innovations" (Moore, 1993, p.76). Moore's conception of business ecosystem can be applied to an ecosystem of societal governance with some reformulations as following, in an ecosystem of societal governance, actors work cooperatively and sometimes competitively to solve public problems and occasionally create opportunities.
} 
According to Jan Kooiman, governing actors not only tackle problems, but also create opportunities. See also Kooiman (2003).

${ }^{7}$ To use Kooiman's distinction of governance orders (first-order / second-order / meta-governance), the argument here focuses on first-order governance, that is "day-to-day activity of public and private actors in concrete governing situations" (Kooiman, 1999, p.78).

${ }^{8}$ In this context, it is worthwhile to refer to the conception of "citizen-society problem solving interface"(von Foerster et al. 1972). Heinz von Foerster and his colleagues tried to design an open and interactive system that can be an interface between citizens and their society (see also Scott (1980)). This pioneering conception points out the importance of a liaison function between actors in civil society. The main purpose of this paper is to categorize a new type of media that fulfill the liaison function.

${ }^{9}$ Actors in societal governance must be accountable for their actions. Openness and accountablity of governing processes enhance their legitimacy as societal efforts. The internet provides actors with a great opportunity to be accountable. They can report on thier activities to the public on their own sites and online campaign platforms. And, in some cases, there need to be institutional procedures or rules to certify them as reliable and skilled actors.

${ }^{10}$ Construction of "public problem" is a part of steering processes of societal governance. Criteria and common sense on what is public are principles of meta-governance (Kooiman, 1999) in societal governance. In their definition of governance, Enderlein et al. eds.(2010, p.2) include finding private solutions to public problems as a part of governing activities, but exclude finding private solutions to private problems. As far as governance is concerned, this is a proper definition. However, when it comes to the problem of social order, which the tradition of sociological theory has been tackling, finding private solutions to private problems is an integral part of the problem.

${ }^{11}$ See FixMyStreet (UK version: https://www.fixmystreet.com/) and SeeClickFix (http://seeclickfix.com/).

12 Partly, we can discuss the first aspect on the context of so-called "Government 2.0" that rethinks a government as a platform provider (O'Reilly, 2009). However, this paper does not focus on the upgrading of the public sector but rather on the role of media that work across the border of the public and the private. Societal media enhance societal efforts on the both sides of the border.

${ }^{13}$ See Razoo (https://www.razoo.com/).

${ }^{1} 4$ See Taproot+ (https://www.taprootplus.org/).

${ }^{15}$ See Causes (https://www.causes.com/).

${ }^{16}$ An explanation of "infrastructure body" in a document of Home Office of the United Kingdom is as follows: "those organizations whose primary purpose is the provision of infrastructure functions (support and development, coordination, representation and promotion) to frontline voluntary and community organizations. They are sometimes called umbrella...or intermediary bodies.” (Kendall ed., 2010, p.73) ${ }^{17}$ See National Council of Nonprofits (https://www.councilofnonprofits.org/).

${ }^{18}$ In U.S. code (42 U.S. Code $§ 12653 \mathrm{~s}$ ), the term "intermediary nonprofit organization" is defined as follows: it "means an experienced and capable nonprofit entity with meaningful prior experience in providing organizational development assistance, or capacity building assistance, focused on small and midsize nonprofit organizations. " In Japan, an organization that is specialized to support NPOs is called as the "intermediary". An official report on the intermediary by Japanese government (Cabinet Office) points out its seven functions: (1) information service, (2) mediation of resources and skills, (3) human resource development, (4) support for better management, (5) coordination and networking, (6) evaluation of NPOs' activities, (7) advocacy and creating common values (Cabinet Office, 2002). 